\title{
PROBLEMATIKA ETIS PENANGANAN VIRUS CORONA COVID-19 1
}

\author{
Raja Oloan Tumanggor \\ Universitas Tarumanagara Jakarta \\ rajat@fpsi.untar.ac.id
}

\begin{abstract}
Abstrak
Pandemi virus Corona Covid-19 bukan hanya menimbulkan persoalan Kesehatan dan politik, tapi juga menyangkus persoalan etika. Apalagi bila berkaitan dengan masalah penanganannya. Setiap kebijakan yang diambil mesti memperhatikan prinsip etis, sehingga tidak membawa persoalan baru dalam diri manusia. Ada beberapa prinsip etis yang ditawarkan dalam artikel ini yakni prinsip deontologis, utilitaris dan etika keutamaan. Ketiganya memiliki kelebihan dan kelemahan masing-masing. Namun yang penting adalah perlu sinergitas antara pemangku kepentingan dan ahli etika dalam pengambilan setiap keputusan, sehingga prinsip persamaan, asas manfaat, prioritas bagi yang paling buruk, dan prioritas bagi yang bertugas menolong orang lain menjadi tolok ukur dalam menangani para korban.
\end{abstract}

Kata-kata kunci: pandemic, Covid-19, persoalan etis

\begin{abstract}
The Corona Covid-19 virus pandemic not only raises health and political issues, but also addresses ethical issues. Especially when it comes to handling problems. Every policy that is taken must pay attention to ethical principles, so that it does not bring new problems in humans. There are several ethical principles offered in this article, namely deontological, utilitarian and virtuous principles. All three have their own strengths and weaknesses. However, what is important is the need for synergy between stakeholders and ethicists in making every decision, so that the principle of equality, the principle of benefit, priority for the worst, and priority for those who are tasked with helping others become benchmarks in dealing with victims.
\end{abstract}

Key words: pandemic, Covid-19, ethical issues.

\section{Pendahuluan}

VIRUS corona baru atau Covid-19 telah merambat hampir di seluruh dunia, sehingga organisasi kesehatan dunia (WHO) menetapkannya sebagai pandemi. Data terbaru yang dilansir dari Worldometers per 28 April 2020 mengemukakan bahwa virus corona telah menjangkiti 3.080.101 orang di seluruh dunia dengan kematian mencapai 212.265 orang dan yang dinyatakan sembuh 929.077 orang. Dalam perhitungan global, Indonesia menduduki urutan 36 dari 210 negara dengan 9.511 kasus di mana 773 meninggal dan 1.254 orang sembuh (Worldometers 28 April 2020).

Berdasarkan data itu virus corona telah menjadi ancaman serius bagi penduduk dunia. Tidak heran berbagai upaya telah dilakukan untuk menanggulangi wabah ini. Dampak yang

${ }^{1}$ Artikel ini telah tayang di Kompas.com dengan judul "Problematika Etis dalam Penanganan Virus Corona Covid-19”, https://www.kompas.com/sains/read/2020/04/28/193000623/problematika-etis-dalampenanganan-virus-corona-covid-19?page=all Abstrak dan daftar pustaka ditambahkan penulis sebagai bahan rujukan untuk pendalaman lebih lanjut. 
ditimbulkan juga kena langsung ke masalah sosial, politis, ekonomis, dan psikologis. Pemerintah melalui berbagai kebijakan ekonomi dan politis berusaha mengatasi. Para peneliti bidang kesehatan bekerja keras di laboratorium mencari vaksin yang bisa meminimalisir, mencegah atau bahkan mengobati penyakit ini. Sementara itu, para dokter dan tenaga medis berjuang di garda terdepan menyelamatkan jiwa para pasien yang terpapar virus corona mematikan itu.

Di sisi lain, penerapan kebijakan pembatasan sosial berskala besar (PSBB) yang saat ini telah berjalan diperpanjang lagi. Physical distancing guna memutus rantai penyebaran virus telah berdampak pada persoalan ekonomis, di mana banyak perusahaan tidak beroperasi, sehingga terpaksa karyawannya di-PHK. Akibatnya, angka pengangguran melonjak dan pekerja sektor informal kesulitan mendapatkan nafkah.

\section{Persoalan etis}

Namun, pandemi Covid-19 bukan hanya menjadi persoalan medis dan ekonomis, tapi juga menyangkut persoalan etis. Etika atau filsafat moral adalah cabang filsafat yang mengulas baik buruknya sikap dan tindakan manusia. Berbagai persoalan etis muncul ke permukaan, dengan yang paling menonjol ialah persoalan di bidang etika medis, karena para dokter dan para perawat harus segera mengambil keputusan ketika berhadapan dengan pasien Covid-19.

Kriteria apa yang harus digunakan para dokter dan perawat untuk menangani pasien Covid-19 yang membludak, padahal tenaga dokter dan perawat amat terbatas? Bila alat bantu pernapasan (ventilator) lebih sedikit dari pada pasien Covid-19 yang sedang sekarat, kepada pasien yang mana alat bantu pernapasan itu mesti diutamakan? Selain persoalan etika medis di atas, muncul juga persoalan etis dari para penentu kebijakan publik. Para kepala negara dan pemerintahan di berbagai belahan dunia termasuk Indonesia telah memberlakukan pembatasan mulai dari tingkat moderat, seperti pembatasan sosial berskala besar (PSBB) hingga lockdown dengan maksud menyelamatkan warga dari Covid-19.

Akan tetapi, dampak dari penghentian kegiatan ekonomi dan bisnis selama pembatasan sosial ini telah menyebabkan jutaan orang menderita karena kehilangan pekerjaan, bahkan ada sebagian sampai mati kelaparan karena tidak memiliki akses menerima bantuan. Dalam menyikapi pandemi Covid-19, para pengambil kebijakan kerap berhadapan dengan keputusan dilematis. Contohnya kebijakan pemberlakuan PSBB.

Di satu sisi, kebijakan itu bertujuan menghentikan penyebaran virus corona agar masyarakat tidak tertular. Namun, di lain pihak, hal itu dapat melumpuhkan roda perekonomian sehingga dapat berdampak pada peningkatan angka pengangguran dan kemiskinan. Kalau PSBB tidak diberlakukan dan roda perekonomian berlangsung normal, angka penularan virus corona diperkirakan akan meningkat tajam. Korban meninggal pun tentu akan semakin bertambah. Teori etika dapat dijadikan sebagai landasan dalam mentukan arah kebijakan. Kalau demikian, tindakan apa yang semestinya dilakukan agar tidak menimbulkan persoalan etis? 
Ada berbagai teori etika yang biasanya dijadikan sebagai landasan untuk bertindak dan mengambil keputusan. Setiap aliran ini memberikan jawaban yang berbeda bila mana seseorang berhadapan dengan persoalan etis. Masing-masing memiliki kelebihan dan juga kelemahan. Pertama, etika deontologis yang mendasari sebuah tindakan pada kewajiban. Etika deontologi menekankan kewajiban manusia untuk bertindak baik. Tindakan itu baik bukan dinilai dari akibat atau tujuan baik dari tindakan, melainkan berdasarkan tindakan itu sebagai baik menurut dirinya sendiri (Bertens, 2004; Sudarminta, 2013).

Etika deontologi menekankan pentingnya kemauan baik dan kesadaran kuat dari pelaku, terlepas dari akibat yang timbul dari perilaku tersebut. Kelemahan etika ini adalah seseorang berhadapan dengan situasi dilematis, misalnya ada dua kewajiban yang saling mengeliminasi satu sama lain, sedangkan keduanya menuntut untuk dilaksanakan. Kedua, etika utilitarianisme yang memandang tindakan yang secara moral benar adalah yang menghasilkan kebahagiaan terbesar bagi warga masyarakat. Suatu tindakan atau keputusan itu dinilai benar secara moral bila menghasilkan hal terbaik bagi banyak orang, baik secara langsung maupun tidak langsung.

Prinsipnya adalah "The greatest good for the greatest number", sebanyak mungkin kebaikan untuk sebanyak mungkin orang. Kendati tampak rasional, etika ini punya kelemahan, antara lain: etika ini secara tidak langsung membenarkan pengorbanan atas minoritas demi mayoritas. Ketiga, etika keutamaan yang berfokus pada pengembangan karakter pada diri setiap orang. Menurut Aristoteles, nilai moral muncul dari pengalaman hidup dalam masyarakat, dari teladan para tokoh besar dalam menghadapi persoalan hidup. Bagi etika keutamaan, nilai moral tidak didikte oleh perintah atau larangan, namun dihayati dari contoh hidup para tokoh tentang kesetiaan, kejujuran, keadilan dan kasih sayang. Seseorang tidak sekadar melakukan perbuatan adil (doing something that is just), tapi adil sepanjang hayat (being a just person).

Manakala seseorang berhadapan dengan situasi dilematis, etika ini memberi jawaban: "Teladanilah sikap dan perilaku moral dari tokoh yang kamu kenal, baik dalam masyarakat atau sejarah saat mereka menghadapi situasi yang sama. Itulah tindakan benar secara moral." Kelemahan etika ini adalah kesulitan menemukan tokoh yang bisa diteladani. Dalam kaitan dengan pandemi Covid-19 yang memunculkan persoalan etis seperti yang sudah diungkapkan di atas, ketiga teori etika deontologi, utilitarianisme, dan etika keutamaan memberikan jawaban yang berbeda terhadap permasalahan etis seperti kriteria apa yang harus digunakan dokter dan perawat dalam merawat pasien Covid-19?

Prinsip etika deontologis berpendapat, dokter dan perawat harus menolong semua pasien Covid19 tanpa pandang bulu karena itu adalah kewajiban dan tanggung jawab tenaga medis untuk menyelamatkan nyawa pasien. Namun, akan muncul persoalan dari sekian banyak pasien yang terpapar dengan tingkat keseriusan yang beragam, prinsip apa yang harus dilakukan? Sementara itu, prinsip utama etika utilitarianisme adalah dampak dari perbuatan. Dokter dan perawat berusaha menyelamatkan sebanyak mungkin pasien Covid-19. 
Adapun etika keutamaan menekankan bahwa jadilah dokter dan perawat yang baik, karena dari pribadi yang baik akan menghasilkan perbuatan yang baik juga. Panduan WHO dan konteks Indonesia Maka, dalam memecahkan berbagai persoalan etis di era pandemi Covid-19 ini, komisi etik Badan Kesehatan Dunia (WHO), misalnya, menerbitkan Ethics and Covid-19: resource and priority-setting yang berisi panduan etis penanganan Covid-19, baik bagi tenaga medis maupun para penentu kebijakan publik. Intinya adalah prioritas apa yang harus dilakukan dalam bertindak dan dapat dipertanggungjawabkan secara etis (WHO, 2020).

Menurut dokumen itu, ada empat prinsip etis yang harus diperhatikan untuk memutuskan individu atau kelompok mana yang harus diprioritaskan dalam pelayanan kesehatan khususnya akses terhadap alat atau sumber daya yang langka. Pertama prinsip persamaan (equality) artinya setiap keinginan orang harus diperlakukan sama. Kedua, prinsip manfaat (utility) artinya alokasi sumber daya langka harus digunakan untuk manfaat semaksimal mungkin demi keselamatan banyak orang. Ketiga, prinsip prioritas bagi yang terburuk (the worst off) artinya sarana diprioritaskan bagi pasien yang paling membutuhkan secara medis.

Keempat, prinsip prioritas bagi orang yang bertugas menolong orang lain, artinya alokasi sumber daya langka pertama-tama diprioritaskan bagi mereka yang punya kemampuan untuk menyelamatkan lebih banyak orang lain. Terhadap penentu kebijakan (decision makers), dokumen Ethics and Covid-19: resource and priority-setting mengemukakan empat prinsip etis yang perlu diperhatikan. Pertama, transparansi (transparency): para pemangku kebijakan mengungkapkan keputusan yang diambil secara transparan.

Publik diberitahu kriteria apa yang mendasari keputusan tersebut. Kedua, inklusivitas (inclusiveness), artinya keputusan yang diambil oleh pemangku kebijakan harus terbuka untuk direvisi. Ketiga, konsistensi (consistency) artinya keputusan harus bersifat konsisten, sehingga semua orang dalam kategori yang sama diperlakukan dengan cara yang sama.

Jadi, tidak ada perlakuan istimewa terhadap golongan tertentu. Keempat, akuntabilitas (accountability) artinya pemangku kebijakan memberi alasan dan bertanggung jawab terhadap keputusan yang diambil. Dalam konteks Indonesia dan kebijakan pemerintah untuk memberlakukan PSBB; keempat prinsip transparansi, inklusivitas, konsistensi, dan akuntabilitas perlu mendapat perhatian. Sejauh mana pemerintah transparan dalam memberikan informasi mengenai pandemi Covid-19 kepada masyarakat? Sejauh mana pemerintah terbuka terhadap kritik atau masukan terhadap keputusan yang diambil? Apakah warga masyarakat yang terdampak Covid-19 memperoleh akses yang sama terhadap bantuan sosial (bansos) yang digelontorkan pemerintah?

Masih banyak pertanyaan yang bisa dilontarkan. Namun, yang pasti pandemi Covid-19 bukan hanya menyangkut persoalan medis dan ekonomis, tapi juga menjadi persoalan etis yang membutuhkan refleksi yang lebih dalam. Maka diperlukan kerja sama dan sinergitas antara berbagai pemangku kepentingan seperti ahli kesehatan, ekonom, penentu kebijakan 
(pemerintah), dan ahli etika, untuk mencari solusi atas persoalan yang muncul di era Covid-19 ini.

\section{Daftar Pustaka}

Bertens, K. (2004). Etika, Jakarta, Gramedia.

Sudarminta, J. (2013). Etika Umum, Yogyakarta, Kanisius.

Worldometers (2020). Coranavirus in:

https://www.worldometers.info/coronavirus/?utm campaign=homeAdvegas1?

WHO (2020). Ethics and Covid-19: resource and priority-setting https://www.who.int/ethics/publications/ethics-covid-19-resource-allocation.pdf?ua=1 